\title{
NASKAH SYAIR KANJENG NABI DAN HIKAYAT NABI BERCUKUR DALAM RELASI EPIGONISTIK
}

\author{
Agus Sulton \\ Kajian Sastra dan Budaya Universitas Airlangga Surabaya. \\ Jl. Dharmawangsa Dalam Selatan. Surabaya 60286 \\ Email: bin.arif@ymail.com
}

\begin{abstract}
Abstrak
Syair Kanjeng Nabi beraksara pegon dan Arab menceritakan Nabi Muhammad sewaktu rambutnya dipotong. Begitu juga dengan Hikayat Nabi Bercukur beraksara Jawi, teksnya mengangkat keadaan Nabi Muhammad saat rambutnya dipotong. Teks ke-duanya menceritakan hal yang sama padahal mempunyai perbedaan geografis. Dari sinilah konsep epigonistik akan difungsikan untuk mengungkap ke duanya, tidak berdasar atas plagiat namun lebih tepatnya sebagai bentuk kreatifitas sang kreator (penyalin). Bentuk hasil kreatifitas itu adalah penulis mencoba menitik beratkan pada identifikasi fungsi naskah dan identifikasi tema, selanjutnya menafsirkan keduanya dari berbagai prespektif budaya dan tradisi penyalinan.
\end{abstract}

Kata kunci: Syair Kanjeng Nabi, Hikayat Nabi Bercukur, Epigonistik, Identifikasi Fungsi Naskah, Identifikasi Tema, Tafsiran Bandingan.

\section{Abstract}

The Kanjeng Nabi Verses (Syair Kanjeng Nabi) is a pegon and Arabic lettered verse that tells us the story about Prophet Mubammad when his hair was cut. The same story is also narrated in the Tale of Shaving Prophet (Hikayat Nabi Bercukur) that was written in Jawi. Both texts tell the similar story despite their different geographical backgorund. This study enables the epigone theory as an approach to controvert the idea on act of plagiarism between authors of both texts then to propose the creator's creativity in producing texts. Identifications on texts 'functions and themes methods, and interpretation on cultural perspectives and transcribing tradition are used in this study in order to demonstrate author's creativity in producing texts.

Keywords: The Kanjeng Nabi Verses, The Tale of Shaving Prophet, Epigone, text function identification, theme identification, comparative interpretation

\section{Pendahuluan}

Kehidupan dunia sastra sebagai bagian dari kebudayaan suatu masyarakat pada gilirannya juga akan mengalami perkembangan sejalan dengan perkembangan kebudayaan masyarakat. Sehingga seperti juga yang terjadi pada kebudayaan. Perkembangan sastra juga akan mengalami saling mempengaruhi antar sastra yang hidup pada masa tertentu, dengan sastra lain di luar masyarakat tersebut. Bentuk keterpengaruhan ini akan beraneka ragam, sesuai dengan tingkat interaksi yang telah dan sedang terjadi. Ini menunjukkan bahwa sebuah karya sastra tidak dapat berdiri otonom, sebuah karya sastra tidak lepas dari karya-karya yang sudah ada. Karya sebelumnya sebagai bentuk kristalisasi, relasi, atau bentuk pengembangan ide.
Menurut pandangan Suwardi Endraswara (2011: 12) bahwa hampir tidak mungkin ada karya sastra tanpa adanya persentuhan dengan karya sastra lain; bahkan karya yang melukiskan hal ihwal kekosongan pun tetap hadir dari suatu keadaan tertentu. Hampir tidak ada karya yang otonom. Karya yang lahir dari kevakuman juga tidak pernah ada. Di tengah persentuhan karya sastra tetap memiliki suatu kreativitas yang layak direnungkan. Persinggungan antar ide, kata, gaya, dan aliran malah bisa memunculkan keunikan lain dengan karya sastra.

Perkembangan suatu masyarakat yang diwujudkan melalui kebudayaan sangat bergantung pada faktor-faktor yang ada pada masyarakat itu sendiri. Salah satu faktor utama adalah manusianya. Tingkat pemikiran manusia yang secara langsung maupun tidak 
langsung terbentuk oleh interaksi dengan alam lingkungannya akan menemukan kedinamisan perkembangan masyarakat tersebut. sehingga tidak menutup kemungkinan terjadi perkembangan kebudayaan yang relatif sama antar budaya suatu masyarakat dengan budaya masyarakat lainnya, walaupun tidak pernah terjadi interaksi. Gejala yang demikian juga terjadi pada dunia sastra. Dalam arti bahwa, karena tingkat perkembangan dan keadaan faktor-faktor yang ada di masyarakatnya mempunyai kedudukan serta kondisi yang sama, maka tidak menutup kemungkinan sastra yang dihasilkan juga relatif sama.

Sastra bandingan dalam hal ini diposisikan sebagai jembatan untuk menganalisis mengenai persoalan-persoalan tersebut. Dalam pandanga Sapardi Djoko Damono (2005: 2) sastra bandingan merupakan bandingan sastra sebuah negara dengan sastra negara lain dan membandingkan sastra dengan bidang lain sebagai keseluruhan ungkapan kehidupan. Konsep Sapardi Djoko Damono hampir sama pada apa yang diungkapkan Suwadi Endraswara (2003: 128) yang menyatakan bahwa, sastra bandingan lebih banyak memperhatikan hubungan sastra menurut aspek waktu dan tempat. Dari aspek waktu sastra bandingan dapat membandingkan dua atau lebih periode yang berbeda. Sedangkan konteks tempat, akan mengikat sastra bandingan menurut wilayah geografis sastra.

Pendapat Sapardi Djoko Damono nampaknya mengarah pada dua asusmsi, yaitu bandingan antar negara dan bandingan sastra dengan disiplin ilmu lain. Namun, Suwardi Endraswara juga menekankan pada dua landasan pokok, yaitu bandingan berdasarkan letak geografis dan bandingan berdasarkan kurun waktu (periode). Dalam makalah Maman S. Mahayana yang disampaikan pada seminar sastra bandingan di Fakultas Sastra (sekarang FIB) Universitas Indonesia, 1990 berpendapat bahwa sastra menyagkut bahasa, wilayah, dan politik. Akan tetapi penulis pada perbandingan kali ini akan menganalisis karya sastra tulisan tangan (manuskrip) dengan bahasa dan aksara yang berbeda dalam ruang lingkup satu negara.

Hikayat Nabi Bercukur, dan Syair Kanjeng Nabi, selanjutnya penulis singkat SKN dan Hikayat Nabi Bercukur disingkat HNB secara relasi antarteks mempunyai kemiripan atau semacam epigon pengarang, atau bisa jadi kreativitas pengarang yang berangkat dari tradisi baru. Dalam bahasa Sunda yang mempunyai persamaan teks dengan Syair Kanjeng Nabi adalah Wawacan Paras Nabi. Naskah (manuskrip) Wawacan Paras Nabi ini terdaftar pada Katalog Jawa Barat Koleksi Lima Lembaga, terdiri atas 36 halaman kertas dengan memakai aksara pegon berbentuk puisi, ukuran kertas $21 \mathrm{x}$ $16,5 \mathrm{~cm}$ dan ruang teks $18 \times 15 \mathrm{~cm}$. Bahkan dalam salah satu episod manuskrip Raja Kandak (tersimpan di PNRI) dan Singir Paras Nabi (tersimpan di perpustakaan UI) menjelaskan mengenai paras Nabi.

Menurut Asdi S. Dipodjojo (1986: 79) Hikayat Nabi Bercukur tersimpan di beberapa perpustakaan di dunia, di PNRI tersimpan tuju buah naskah, selanjutnya tersimpan di Leiden, London, dan di 'sGravenhage. Naskah Hikayat Nabi Bercukur terdiri atas beberapa macam bahasa, misalnya bahasa Makasar, bahasa Bugis, bahasa Sunda yang pernah dimuat oleh Grashuis dalam buku bacaannya pada tahun 1874, dan bahasa Aceh dengan nama Nabi Meucuko. Hikayat ini juga pernah diterbitkan di Jakarta pada tahun 1953 dan di Singapura sampai berulang kali terbit.

Sastra dalam lingkup manuskrip hampir semuanya mempunyai variasi teks, entah teks itu lebih luas atau menyempit. Ini tugas filologi sebagai kerja merunut teks naskah asli atau naskah yang mendekati asli. Tetapi naskah SKN dan HNB akan diperlakukan relasi antarteks sebagai bentuk epigonistik. Sebenarnya masih banyak sekali karya sastra lama yang mempunyai relasi antarteks, namun penulis mengambil SKN dan HNB mencoba untuk dianalisis karena kedua manuskrip ini terdapat kemiripan tetapi dalam SKN ada tambahan teks asmaul husna. Begitu juga bentuk penyampaian teks berbeda; manuskrip SKN disampaikan (tulis) dalam bentuk syair. 
Selanjutnya sebagai pembanding lain, yaitu manuskrip yang berbeda aksara dan bahasa, yaitu manuskrip HNB.

\section{Deskripsi Objek Bandingan}

Manuskrip Hikayat Nabi Bercukur dan Syair Kanjeng Nabi akan diungkan bandingan kandungan teks. Apa ada berbedaan yang singnifikan dari keduaya, padahal ketiga naskah itu dimunculkan dalam kondisi dan budaya masyarakatnya yang berbeda. Namun secara inti, teks keduanya membicarakan Nabi Muhammad SAW bercukur disertai fungsi teks.

Penarikan keterpengaruhan ketiganya penulis menjadikan SKN sebagai inti atau tonggak pegangan, bukan artian yang lebih lengkap, tetapi sebatas membatasi teksnya. Pada akhirnya kedua teks itu mampu dicari kesamaannya. Singkat deskripsi teks SKN, yaitu Nabi Muhammad lahir di Makah anak laki-laki dari kyai Abdullah ibu Dewi Aminah, selama masih dalam kandungan, ayah Nabi Muhammad sudah meninggal dunia. Tidak begitu lama setelah kelahiran Nabi Muhammad sang bunda Dewi Aminah menyusul suaminya dan dimakamkan di Abwa juga. Dalam posisi seperti itu, Nabi Muhammad berada di kota Madinah diasuh oleh pamannya, yaitu Abu Tholib, seorang putra Abdul Muthalib.

Selang beberapa tahun Nabi Muhammad kembali ke Mekah dan menikah dengan Siti Khodijah. Tidak begitu lama, malaikat Jibril menyampaikan wahyu kepada Nabi Muhammad di Gua Hira. Awalnya setelah Nabi Muhammad mendapatkan wahyu, kemudian berdakwah ke kerabatnya dan berlanjut ke kaum Quraisy didampingi oleh para sahabat Nabi yang telah sepakat mempercayai terhadap syariat Islam.

Dari sedikit ringkasan cerita awal teks tersebut, SKN berisi tentang keluarga Nabi antara lain ayahnya (Abdullah), ibunya (Dewi Aminah), kakeknya (Abdul Muntholib), dan istrinya (Siti Khodijah). Dalam cerita teks SKN selanjutnya lebih kepada ajaran (dakwah) syariat Islam yang dikonsep dalam bentuk syair dan doa-doa mujarab atau syair doa.
Identifikasi Keterkaitan Fungsi Manuskrip

Pemaparan dalam penelitian ini akan membatasi persoalan-persolan pokok terutama mengenai fungsi naskah, tema, dan relasi keduanya. Fungsi naskah (manuskrip) adalah nilai lebih dari suatu naskah tersebut, hal ini ada hubungannya dengan tema karena tema atau kandungan teks itulah yang mempunyai suatu keistimewaan. Keduanya ada harapan bahwa kedua naskah yang dijadikan analisis merupakan suatu relasi. Relasi itu kemungkinan ada pengaruh epigonistik.

Ketiga persolan itu sekedar menjembatani simpulan atau titik temua bagian mana saja yang terletak kemiripannya dengan cara komparasi, kemudian ditafsirkan sederhana apakan HNB dan SKN ada pengaruh unsur epigonistik. Menurut Suwardi Endraswara (2011: 112) epigon berasal dari bahasa latin, yaitu epigonos atau epigignestai, yang berarti terlahir kemudian. Seniman atau sastrawan adalah kreator yang gemar melakukan penjelajahan imajinasi. Melalui imajinasi tentu ada hal yang baru, atau suatu penolakan terhadap yang dahulu, dan tidak tertutup kemungkinan ada inovasi. Apapun wujudnya, kemampuan sastrawan menciptakan perlu dihargai sebagai kreatifitas. Biasanya karya yang lahir terdahulu sering dijadikan induk epigon, sedangkan karya berikutnya disebut epigon.

Titik temu epigon pada akhirnya secara otomatis akan terdeteksi berdasarkan komparasi keduanya dari sudut penokohan dan temanya. Sajian pertama ditemukan fungsi orang yang menyimpan teks naskah dari keduanya.

"sabab agamane dak erti / sing safa simfen ing caritane / maka selamet ing sak umure/ maka sun faring rahmat sak leksa I saben wengi lawan den reksa / sing dak gelem simfen ing caritane / ingsun kurai ing sak usine / lan sun kurai sandang paane / sekehe ferabot jero omahe / yen wong kang demen carita rasul / ulehe faras ing kanjeng rasul / jin lan syethan iku dak wani / tur dadi syabid besuk matine / lan yen lara ya gelis waras / oleh berkate nabi fefaras / lan lamun sira aref leluan / festhi selamet sekehe begal / lan selamet 
maring kesasar / miwah selamet kala leluan / / "(SKN)

\section{"sing simfen ing caritane / ingsun sefura sekeh dusane" (SKN)}

'barang siapa menaruh perilaku bercukur ini, maka Allah ta'ala menurunkan rahmat-Nya dibalas rumah kamu berpuluh amal dan beberapa rizki" (HNB)

Kedua teks tersebut menyajikan fungsi dari naskah itu sendiri bahwa teks Nabi Muhammad bercukur mempunyai fungsi. Fungsi dari keduanya terdapat kemiripan antara lain: a) SKN menjelaskan bahwa barang siapa yang mau menyimpan naskah SKN jin dan setan tidak berani, akhirnya akan mati sahid, apabila sakit akan cepat sembuh, apabila akan bepergian akan selamat dari perampok, dan dimaafkan dari semua banyaknya dosa dan b) teks HNB kalau disimpan makan akan diberikan rahmat oleh Allah, dan berpuluh amal serta rizki.

Selain menyimpan naskah, ternyata cerita Nabi Muhammad bercukur juga ada hikmah dibalik menulis naskah. Menulis di sini diartikan sebagai menyalin. Seperti pada kutipan di bawah ini: "yen dak bisa maca do'a tulisan / maka simpena iku tulisan / maka areksa allah ta'ala" (SKN). Dalam teks HNB tidak dijelaskan secara spesifik akan makna dari menyalin naskah cerita Nabi Muhammad. Fungsi menyalin hanya diketemukan pada naskah SKN, yaitu barang siapa yang menulis (menyalin) naskah akan terhindar dari kejelekan dan di surga mendapat bidadari.

Arti membaca dalam hal ini, penulis artikan melafalkan tanpa teks dan membaca menggunakan teks naskah.

"lan akeh akeh iku syawabe / lamun den waca iku do'ane / dak kurang resqi kang selawase / den padaaken ing kuburane / kala sekarat iku dak lara / munkar wa nangkir / I dak nakoni / dina kiyamat dak melebu geni lan selamet ing foncabaya / jin lan syethan dak niyaniya / allah ta'ala annyugehaken / ikilah do'a den amalaken / sartane lufut sekehe belabi

\section{/ besuk qiyamat lufut ing geni / allah ta'ala} ambagusana" (SKN).

"Barang siapa perdayakan padanya, nescaya bertambah rahmat Allah turun pada rumahnya pada sehari-hari jua adanya"(HNB).

Dari kedua teks tersebut terdapat fungsi yang berbeda. Kemungkinan perbedaan fungsi tersebut karena proses penyalinan. Naskah yang disalin bisa jadi sebuah ringkasan, menjelaskan sebatas inti pokok teksnya. Secara garis besarnya tema dari fungsi naskah penulis bagia dalam tiga tahapan yaitu tahap menyimpan menyalin, dan membaca. Tahap membaca dari cerita Nabi Muhammad bercukur fungsinya tertera pada kutipan teks di atas, seperti: a) "apabila membaca teks naskah SKN maka tidak akan kekurangan rizki selama-lamanya dilapangkan kuburnya, ketika mati (nazak) tidak sakit, malaikat Mungkar dan Nangkir tidak adan menanyai, hari kiamat tidak akan masuk api neraka, dan selamat dari mara bahaya. Di samping itu jin dan setan tidak akan menggoda (sia-sia), Allah SWT memberikan kekayaan. Apabila hal itu dilaksanakan, nantinya bisa terhindar dari bahaya api neraka dan barang siapa yang ragu pasti kufur" dan b) "apabila membaca HNB maka Allah SW'T akan menurunkan rahmat di rumah orang yang membaca itu setiap hari".

Keduanya mempunyai fungsi yang berlainan, padahal fungsi yang dimaksudkan adalah membaca cerita Nabi Muhammad bercukur. Termasuk berasal dari daerah yang berbeda-beda dan masa yang berbeda. Dalam SKN sendiri tercantum kolofon - hataman syiir ing dina abad / nyerambahana maring wong tobat / tanggal wolulas rabiul awal / syufa'at den enggalenggal fukul fitu fasaran wage / bisaha metu nyang ageage / bijrahe sewu telung atus / lan rong pulub fitu funjule." Syair ini selesai ditulis (salin) hari Minggu, tanggal 18 Rabiul Awal, jam 7 pasaran Wage, bulan Hijriah 1327 (1906). Naskah HNB berasal dari museum negeri Banda Aceh, di dalam deskripsi dijelaskan kalau naskah HNB memakai kertas watermark Bulan Sabit Bersusun Tiga, sekitar tahun 1696 M. 
Menurut Abdul Hadi WM (2007) kesusastraan Melayu dan Jawa merupakan dua kesusastraan serumpun yang khazanahnya begitu kaya dan sangat berpengaruh terhadap perkembangan kesusastraan Nusantara yang lain. Selanjutnya Suwardi Endraswara menambahkan, saling berpengaruh antara keduanya sebagai dampak dari keterjalinan budayanya, menyebabkan kedua ranah kesusastraan itu kaya bahan penelitian sastra bandingan. Baik dalam khazanah kesusastraan Melayu maupun dalam khazanah kesusastraan Jawa terdapat karya-karya saduran dan gubahan dari sumber yang sama, dipengaruhi dan diilhami oleh sumber yang sama, serta ditulis berdasarkan pandangan estetika pada paham keagamaan yang sama.

\section{Identifikasi Tema}

Tema adalah pokok pembahasan dari persoalan dalam sebuah teks. Tema cerita Nabi Muhammad sangat luar biasa banyaknya. Mulai dari masa kelahiran sampai meninggalnya Nabi Muhammad. Cerita-cerita itu di Nusantara dikreasikan menjadi beragam bahasa dan versiversi yang sifatnya jalinan. Dalam teks Syair Kanjeng Nabi mempunyai persamaan dengan teks-teks sejenis, seperti HNB.

Pada awal teks SKN dimulai dengan cerita NabiMuhammad adalah anak laki-laki Abdullah, dan ayahnya meninggal kamudian dimakamkan di Abwa sebelum Nabi Muhammad lahir. Setelah kelahiran Nabi Muhammad ibunya meninggal dimakamkan dekat Abdullah. Dalam kondisi tanpa ayah dan ibu, Nabi Muhammad dirawat oleh Dewi Aminah di kota Madinah sampai dewasa akhirnya menikah dengan Dewi Khodijah.

\footnotetext{
"futera jalere kiyahi abdullah / finuteraken ana ing makkah / durue zhahir njeng rasulullah / den tilar sedara den abdullah I nalike sedara den abdullab / iku benere ana abuwa / / den sarekaken ana madinah / kari rerandan dewi aminah / sarta aandut njeng rasulullah / tur masi tetep ana ing mekah / sawuse fahir menyang mudinah / den susuaken dewi halimah / lawase lawas bali nyang makkah / den aturaken / dewi aminab / den ejak
}

lua maring madinah / ibune seda ana abuwa / sanding kang rakara den abdullah / den karekaken ana madinah / nabi mubammad bali nyang mekah / melase garwa dewi hadijah" (SKN)

Pada permulaan teks SKN dijelaskan secara singkat kelahiran Nabi Muhammad sampai beristri dengan Dewi Khodijah. Hal ini tidak diketemukan peristiwa itu pada teks HNB. Cerita Nabi Muhammad bercukur dalam teks SKN dimulai pada saat salah satu orang mukmin datang ke Abu Bakar, kemudian Abu Bakar menjawabnya, seperti pada kutipan:

"ya abu bakar ratune mu'min / ing dawnh tuwan kula kefiin / kalane faras njeng rasulullah / dinane sasi niku funafa / duk miyosi kuluk kang pundi / den fariaken ing kanjeng nabi / ya abu bakar iku andika 9 ing wong mu'min kang fada teka // tetkala faras nabi mubammad / bakdane kundur kang perang lahad / ing dina isnain wus ana makkah / iku kundure saking madinah / njeng gusti darus qur'an sak saat / maka katekan ing malaikat jabarail mbekta kalimah ayat I den fariaken kekasih tuwan / mukholikina ru'usakum / wamuqashirina latakhafuna / punika werni ing ayat qur'an/ ...sa'alas ramdan sagale sasi"'(SKN)

"maka datanglah seorang daripada kaum sahabat nabi Allah. Maka dia pun bertanya kepada Abu Bakar Sadiq Radiallahu anhu bertanya apalah kiranya peri kemuliaan mukjizat nabi Allah bercukur itu. Di hadapan siapa nabi Allah bercukur itu dan kopiah daripada mana akan dipakai nabi Allah bercukur itu dan berapa tahun lamanya sudah nabi Allah bercukur. Maka ujar Abu Bakar alSiddiq radiallahuanhu demikian bunyinya, 'Hai mukmin yang percaya akan Allah, jika tuan hamba hendak mendengar peri kemuliaan mukjizat nabi Allah bercukur itu baiklah, hamba ceterakan kepada tuan hamba'.... Adapun tatkala nabi Allah bercukur itu waktu Rasulullah kembali daripada perang dengan Raja Lahud pada sembilan hari bulan Ramadhan hari isnin tatkala membaca Quran pada ketika itu ia turun dibawa oleh Jibril kepada nabi demikian muhalliqunarausikumuilaihi ...sembilan belas hari bulan Ramadhan pada hari isnin" (HNB). 
Dalam teks tersebut seorang mukmin bertanya mengenai hari dan bulan saat Nabi Muhammad bercukur. Setelah bercukur harus memakai topi apa sekiranya pantas untuk Nabi Muhammad. Kemudian Abu Bakar menjawabnya bahwa Nabi Muhammad bercukur pada hari Senin sepulang dari perang Lahad tepat sudah berada di Makkah. Tanggal 19 bulan Ramadhan. Sedangkan pada teks HNB menyatakan kalau Nabi Muhammad bercukur setelah pulang perang melawan Raja Luhud pada sembilan belas hari bulan Ramadhan, tepat hari Senin. Kedua teks itu mempunyai kemiripan dari apa yang ditanyakan oleh seorang mukmin kepada Abu Bakar dan atas perintah Allah hari mulainya Nabi Muhammad bercukur.

Selain itu di teks SKN, sepulang dari Madinah Nabi Muhammad membaca Al Qur'an sebentar, kamudian malaikat Jibril datang dengan membawa ayat "mukholikina ru'usakum/ wamuqashirina latakhafuna" $\mathrm{Hal}$ yang sama juga muncul di teks HNB, malaikat Jibril datang dengan membawa ayat "muhalliqunarausikumuilaihi".

Selesai tanya jawab seorang mukmin dengan Abu Bakar, dan dilanjutkan malaikat Jibril datang dengan membawa ayat. Kemudian atas izin Nabi Muhammad Jibril datang kepada Allah menanyakan mengenai topi yang akan digunakan setelah Nabi Muhammad Bercukup, seperti:

"ya ilaybi anta faeran / fundi kuluk kasibe tuwan / kebat lu'aha menyang suwarga / sira menika godong kastuba / ingkang sak lembar gawe kuluke / kekasih ingsun maring farase \& nuli jabarail menyang suwarga \% menika godonge kayu kastuba / amung sak lembar lir sutera ijo / / " (SKN).

"maka firman Allah ta'ala kepada Jibril 'Adapun kekasihku itu bercukur di hadapan cahaya dirinya jua kerana ia cahaya nabi- nabi dan yang mencukur kekasihku itu engkau Jibril dengan firmanku dan kopiah yang akan dipakai kekasihku jika sudah bercukur ambil olehmu daun kayu Tuba yang amat hijau warnanya di dalam syurga, perbuat olehmu akan kopiah kekasihku daripada nugerahku"' (HNB).
Topi yang dipaparkan dari kedua teks tersebut adalah topi dari daun kastuba yang diambil oleh malaikat Jibril dari surga sutera (SKN) berwarna hijau. Pemakaian topi itu berdasarkan perintah Allah yang diberikan kepada malaikat Jibril. Pada saat bercukur Nabi Muhammad disaksikan oleh empat para sahabat Nabi. Mengenai jumlah rambut Nabi Muhammad juga dimunculkan dalam kedua teks manuskrip itu, seperti pada kutipan:

"katabe rambut tuwan wunia / niku sak keti lan telung leksa / lan telung ewu lan telung atus / lan telung fulub telu den urus / /" (SKN).

"adapun banyak rambut tuan hamba itu, sakti dua laksa enam ribu enam ratus enam puluh enam helai" (HNB).

Dalam SKN banyaknya rambut Nabi Muhammad adalah satu keti (10.000), satu leksa (100.000), tiga ribu, dan tiga ratus; berarti total keseluruhan 113300. Hal ini berbeda dengan teks HNB yang menjelaskan kalau jumlah rambut Nabi Muhammad adalah satu keti (10.000) dua leksa (200.000), enam ribu enam ratus enam puluh enam (6.666); berarti total 216.666.

Berlangsungnya Nabi Muhammad bercukur oleh malaikat Jibril, Allah menurunkan firman kepada para bidadari di surga. Mereka disuruh untuk turun ke bumi untuk menyaksikan bercukur, dan disuruh untuk mengambil sehelai rambut-Nya, seperti pada kutipan:

"he widadari fada mudhuna / menya'a mekah fada nuntana / olehe faras nabi mubammad / ingkang marasi ya malaikat / sira mareka jaluk rambute / sak lembar ewn akeh syawabe / sirata lekena ing le'en ira / sekeh dusamu isun sefura / sing simfen ing caritane / ingsun sefura sekeh dusane" (SKN).

"maka firman Allah ta'ala menitahkan segala anak bidadari 'Hai anak-anakan bidadari keluarlah engkau sekalian dari dalam syurga, pergilah engkau segera turun ke dunia mengambil 
rambut kekasihku yang dicukur oleh Jibril dan sehelai rambutnya pun janganlah gugur ke bumi. Ambillah olehmu sehelai seorang akan mukjizat, ikatkanlah pada lengan kamu yang kanan supaya kuampuni sekelian dosa kamu"” (HNB).

Manuskrip SKN menyebutkan jenis rambut Nabi Muhammad ada seribu macam, tetapi pada teks HNB tidak disebutkan jenisnya. Namun pada kedua teks manuskrip menjelaskan bahwa bagi siapa yang mau mengambil rambut Nabi Muhammad kemudian letakkan di lengan kanan (HNB) atau kedua lengan (SKN), maka semua dosa akan diampuni oleh Allah.

\section{Penafsiran Perbandingan}

Penafsiran merupakan persoalan mempertimbangkan keterpengaruhan dalam mencari sebab suatu teks tersebut mempunyai titip mirip dengan teks lain. Bisa jadi teks itu mengalami penyempitan atau perkembangkan teks berdasarkan kreatifitas penyalin atau penafsir naskah. Semakin kreatif seorang penyalin manuskrip itu maka semakin beragam pula teks itu dimunculkan. Kemungkinan lain, memang penyalin manuskrip sengaja mengurangi teks tersebut dengan maksud lain. Penyalin adalah orang yang melakukan penyalinan teks naskah berpedoman atas naskah rujukan yang ada.

Berdasarkan pengamatan Edwar Djamaris (2002: 5-6) penyalinan naskah membaginya menjadi bermacam-macam cara, sebagai berikut: a) penyalin menyalin suatu naskah secara otomatis, tidak cermat dan tidak memperhatikan isi kalimat naskah yang disalinnya itu, sehingga naskah itu sering terjadi kesalahan tulis, b) penyalin menyalin naskah dengan sengaja mengubah kata, menambah, dan mengurangi kata kata atau susunan kalimat yang dianggapnya salah itu, sehingga naskah semacam ini terdapat banyak kata atau kalimat yang berbeda, c) penyalin menyalin suatu naskah dengan gaya bahasanya sendiri sehingga terdapat beberapa naskah yang gaya bahasanya berbeda, dan d) teks naskah itu disalin dari teks lisan. Sudah barang tentu dalam menulis teks lisan itu ada beberapa bagian yang lupa atau susunan cerita yang berbeda.

Pengamatan yang dilakukan Sri Wulan Rujiati Mulyadi lebih sederhana. Beranggapan, penyalinan naskah di Indonesia mempunyai kebebasan. Dalam artian, penyalin bebas memberbaiki kesalahan teks naskah yang dianggap salah di dalam naskah yang disalin, misalnya mengubah, menambah, dan mengurangi menurut seleranya.

Pengertian itu bisa dilihat pada beberapa manuskrip Melayu dan Jawa, keduanya mempunyai pengaruh besar terhadap titik mirip. Letak kemiripan ini yang penulis jadikan sebagai titik epigon dari hasil inovasi. Menurut Sapardi Djoko Damono (2005: 18-25) menjelaskan beberapa poin keterpengaruhan dari sastra bandingan, yaitu asli, pinjaman dan tradisi. Tradisi inilah yang mendapati letak kemunculan epigonistik. Tradisi adalah penuturan teks yang turun- temurun.8 Sementara itu Siti Baroroh Baried, dkk (1994: 59) tradisi adalah rangkaian penurunan yang dilewati oleh suatu teks yang turun-temurun. Baik teks itu berupa teks naskah turunan atau teks lisan.

Tradisi ini sangat berpengaruh akan kelangsungan suatu kerya itu mengalami epigonistik, seperti SKN dan HNB. Keduanya sama-sama menceritakan tentang Nabi Muhammad bercukur disertai fungsi teks naskah. SKN disalin 1906 M, sedangkan HNB 1696 M. Apakah SKN pegon terlahir kemudian setelah HNB Jawi, padahal Sunan Kalijaga juga menuslis Serat Paras Nabi memakai aksara pegon. Hal ini harus merunut Islam di Nusantara dan karya-karyanya. Menurut Ismail Hamid (1983: 19) cerita-cerita kisah nabi versi Melayu banyak digubah berdasarkan sumber Arab dan Parsi seperti Kitab al-Mubtada wa Qisas al- Anbiya' (buku tentang kejadian alam dan cerita para nabi) karangan Wahb ibn Munabba (w. $730 \mathrm{M}$ ), Ara is al-Majalis: Qisas al-'Anbiya“ (para pengantin dalam majlis: kisah para nabi) karangan Tha 'labi (abad ke-10 M), dan Qisas al'Anbya'karangan Ibn Khalaf dari Nisyapur. 
Suatu kemungkinan naskah cerita Nabi Muhammad bercukur dari berbagai bahasa di Nusantara merujuk dari sumber yang sama, tak terlepas mendapat tafsiran dari para kreator waktu itu. Karena Islam masuk Nusantar dengan cara damai, dan nilai keutuhan lokal tetap dilestarikan. Sastra Islam yang dikemas menjadi hikayat dan syair tentang tokoh kepahlawanan inilah orang-orang Nusantara terpengaruh, pada akhirnya memberikan kesan kepada pembaca atau pendengar waktu itu bahwa tokoh-tokoh Islam itu sangat hebat. Dengan cara ini menutup kemungkinan ajaranajaran Islam mudah diterima oleh masyarakat.

\section{Kesimpulan}

Teks SKN dan HNB dari wilayah yang berbeda sama-sama menceritakan mengenai Nabi Muhammad pada saat bercukur, disertai dengan fungsi naskah. Namun kesamaan itu tidak secara singnifikan dimunculkan. Banyak berbedaan yang nampak, mulai dari kelahiran Nabi Muhammad ada dalam teks SKN sedangkan di HNB tidak diketemukan, termasuk tambahan teks asmaul busna dari SKN. Fungsi naskah masing-masing juga ada sedikit perbedaan antara di Melayu dan di Jawa. Kalau Naskah SKN lebih beragam nilai- nilai fungsinya bila dikomparasikan dengan naskah HNB.

Perbedaan proses penyalinan atau penafsiran tidak lepas dari pengaruh sosial dan budaya dari mana suatu karya itu dimunculkan. Epigonistik sebagai alat untuk mengembangkan kreatifitas penyalin agar memberikan pengaruh bagi pembaca atau pendengar akan sebuah teks "tradisi" bersastra.

\section{Daftar Pustaka}

Baried, Baroroh, dkk. 1994. Pengantar Teori Filologi. Yogyakarta: Badan Penelitian dan Publikasi Fakultas (BPPF) Seksi Filologi, Fakultas Sastra UGM.

Damono, Sapardi Djoko. 2005. Pengantar Penelitian Sastra Bandingan. Jakarta: Pusat Bahasa, Depdiknas.

Dipodjojo, Asdi S. 1986. Kesusastraan Indonesia
Lama Pada Zaman Pengaruh Islam. Yogyakarta: Lukman.

Djamaris, Edwar. 2002. Metode Penelitian Filologi. Jakarta: CV Manasco

Endraswara, Suwardi. 2003. Metodologi Penelitian Sastra. Yogyakarta: Pustaka Widyatama.

Endraswara, Suwardi. 2011. Metodologi Penelitian Sastra Bandingan. Jakarta: bukupop.

Hamid, Ismail. 1983. Kesusasteraan Melayu Lama dari Warisan Peradaban Islam. Petaling Jaya, Selangor: Fajar Bakti.

Manuskrip Syair Kanjeng Nabi. Manuskrip Hikayat Nabi Bercukur.

Pradopo, Rahmat Djoko. 2005. Pengkajian Puisi: Analisis Strata Norma dan Analisis Struktural dan Semiotik. Yogyakarta: Gajah Mada University Press.

Pusat Bahasa Departemen Pendidikan Nasional. 2007. Kamus Besar Bahasa Indonesia. Jakarta: Balai Pustaka

Saputra, Karsono H. 1992. Pengantar Sekar Macapat. Depok: Fakultas Sastra Universitas Indonesia.

Tjandrasasmita, Uka. 2009. Arkeologi Islam Nusantara. Jakarta: Kepustakaan Populer Gramedia 